\title{
Comparing safety climate in infrastructure and building projects in Indonesia
}

\author{
Riza Yosia Sunindijo ${ }^{1, *}$, Martin Loosemore ${ }^{1}$, Fatma Lestari $^{2,3}$, Yuni Kusminanti ${ }^{3}$, Baiduri Widanarko ${ }^{2}$, Cynthia \\ Febrina $^{3}$ and Fiori Amelia ${ }^{3}$ \\ ${ }^{1}$ Construction Management and Property, Faculty of Built Environment, UNSW Sydney, NSW 2052, Australia \\ ${ }^{2}$ Occupational Health and Safety Department, Faculty of Public Health, Universitas Indonesia, Kampus Baru UI Depok, West \\ Java 16424, Indonesia \\ ${ }^{3}$ Occupational Safety, Health and Environmental (OSHE) Unit, Universitas Indonesia, Kampus Baru UI Depok, West Java \\ 16424, Indonesia
}

\begin{abstract}
Despite the rapid growth of the Indonesian construction industry and its significance to the national economy, health and safety in the industry remains poor. This research focuses on safety climate, a popular indicator of health and safety performance that has not been adequately investigated in the Indonesian construction industry despite the size of the country and the poor health and safety record of the industry. Specifically, this research aims to compare the safety climate levels in infrastructure and building projects and identify factors that account for their differences or similarities. A safety climate questionnaire was distributed to respondents working in an infrastructure project and two medium-rise building projects, where 311 respondents participated in total. The findings show that the building projects have a higher level of safety climate than the safety climate in the infrastructure project despite the fact that the infrastructure project was managed by a joint venture involving international contractors known for their health and safety commitment. We argue that project complexity is the main factor responsible for explaining this difference. Complex projects require stringent enforcement of health and safety rules and procedures, and supportive work environments conducive for health and safety implementation.
\end{abstract}

\section{Introduction}

As the largest economy in Southeast Asia, Indonesia's economy is robust and growing by more than $5 \%$ annually. Driven by a growing population, increased urbanisation, favourable demographics, and a strong commitment from the government to invest in infrastructure, the Indonesian construction industry is expanding rapidly at $8.1 \%$ in 2017 [1]. The Indonesian Government recognises the importance of the construction industry in supporting economic growth and in improving the social and economic infrastructure of the country. The government's commitment on infrastructure development is reflected in the infrastructure budget which has been increased by $30 \%$ annually on average since 2015 [2].

This rapid growth, if not managed carefully, can have detrimental effects on health and safety performance. Occupational Health and Safety in Indonesia is currently managed under Law No. 11970 on Occupational Safety, Law No. 231992 on Occupational Health, and Law No. 132003 on Employment. The Indonesian Government, recognising the need to improve its health and safety records, further issued Government Regulation No. 50 on Occupational Safety and Health (OSH) Management Systems in 2012, which requires the establishment of OSH management systems in every organisation employing 100 workers or more or that has a high level of potential hazard [3]. There are also other regulations and procedures that cover various aspects of OSH or provide details on how to implement the laws.

Despite these laws and regulations, the OSH record in the Indonesian construction industry remains poor. There were over 50,000 recorded workplace accidents across Indonesian industries in 2015 and nearly a third occurred in the construction industry [4]. Health and safety is generally considered as an unnecessary cost burden and its awareness is still low [5]. This issue is significant because there is an abundance of evidence showing the adverse effects of poor OSH on project performance indicators, worker morale, productivity, and business reputation $[6,7]$.

Within the context of the Indonesian construction industry, this research focuses on safety climate as an

* Corresponding author: r.sunindijo@unsw.edu.au 
indicator that reflects a dimension of health and safety performance. Safety climate has been used to predict health and safety performance across industries for years. It is also considered as a reliable indicator to assess health and safety performance in the construction industry [7-9]. As a leading indicator, safety climate is able to identify health and safety problems before they manifest themselves into accidents and it provides a mechanism for construction organisations to identify problematic areas, thus providing focus to optimise effort on health and safety improvements $[10,11]$.

Research on safety climate in the Indonesian construction industry is limited despite the size of the country and the poor health and safety record of its construction industry. Therefore, the aim of this research is to assess the levels of safety climate in construction projects in Indonesia. This research specifically focuses on two types of construction projects: infrastructure and building projects. The building projects were relatively simple and managed by local construction organisations, while the infrastructure engineering project was complex, the first of its kind in the country, and was managed by a joint venture involving international construction organisations. This research addresses two research questions. First, is there any significant difference between safety climate levels in infrastructure and building projects in Indonesia? Second, what are potential factors that explain their differences or similarities? As such, the objectives of the research are to, first, determine whether there is any difference between the safety climate level in an infrastructure project and the level in building projects in the Indonesian construction industry, and, second, to discuss potential factors that may be responsible for their differences or similarities.

\section{Safety Climate in the Construction Industry}

The term safety climate was first coined by Zohar [12], who defined safety climate as "a summary of molar perceptions that employees share about their work environments" (p. 96). He argued that these perceptions serve as a frame of reference for employees to behave and that the management has an important role to play to influence these perceptions that can improve health and safety performance in the organisation.

The terms safety climate and safety culture have been used interchangeably and have caused a lot of confusion on what they actually refer to. Safety culture is a set of values, perceptions, attitudes and patterns of behaviour with regard to health and safety shared by members of the organisation; as well as a set of policies, practices and procedures relating to the reduction of employees' exposure to occupational health and safety risks, implemented at every level of the organisation, and reflecting a high level of concern and commitment to the prevention of accidents and illnesses [13]. In the same vein, Health and Safety Executive [14] proposed three distinct but interrelated dimensions of safety culture: psychological, behavioural, and corporate. The psychological dimension refers to how people feel about safety and safety management systems. The behavioural dimension is concerned with what people do within the organisation, which includes the safety-related activities, actions, and behaviours exhibited by employees. The corporate dimension can be described as what the organisation has, which is reflected in the organisation's policies, operating procedures, management systems, control systems, communication flows, and workflow systems. The psychological dimension of safety culture is actually safety climate, which encompasses the attitudes and perceptions of individuals and groups towards health and safety. This shows that safety climate is in fact part of safety culture [7, 14-16].

Zohar's [12] work on safety climate has gained wide recognition resulting in safety climate becoming a focus of health and safety research and being used as a proxy of health and safety performance. As such, considerable research has been conducted to identify safety climate dimensions and develop safety climate measurement tools (for example see Beus [17]; Dedobbeleer and Béland [8]; Mohamed [9]). Collectively, Zou and Sunindijo [7] identified the following safety climate dimensions from previous literature:

- Management commitment. Employees must perceive that managers are committed to safety and consider safety as equally important as other measures of organisational performance, such as productivity and profit [12].

- Communication. This refers to regular informal and formal communication between managers and the workforce about health and safety issues and the need to work safely [18].

- Safety rules. Safety policy, rules, and procedures must be perceived as practical, realistic, and appropriate [7, 18].

- Supportive norms. This refers to the degree of trust and support in the workplace, including relationships with superiors, relationships with coworkers, and overall work conditions that are conducive to health and safety [9].

- Personal accountability. The workforce should value health and safety and be actively involved in developing health and safety initiatives rather than being passive recipients of safety policy and procedures from the top $[19,20]$.

- Safety training: Health and safety training must be perceived to be effective in providing sufficient knowledge for employees to identify safety risks and perform their works safely [9].

Despite its popularity, safety climate studies in the Indonesian construction industry are limited. Andi [21] and Machfudiyanto et al. [22] identified dimensions of safety climate, which include management commitment and leadership, safety rules and procedures, communication, work environment, worker competence, and worker involvement. Sutalaksana and Syaifullah [23] found that positive safety climate reduces work pressure and barriers to work safely, and promotes safe behaviour, while Irawadi [24] found that safety climate 
predicts safe behaviour and positive project performance in high-rise building projects in Indonesia.

\section{Research Methods}

A questionnaire survey was used to assess the levels of safety climate in construction projects in Indonesia. The survey has been used successfully in Indonesian contexts before. Based on its previous uses, items that had high inter-correlation and were measuring the same or very similar items were removed. Five items to assess the health and safety training dimension were added into the questionnaire.

The questionnaire has two sections. The first section collected data about respondent demographics, including age, gender, and number of years working in the construction industry. The second section sought to assess safety climate and consists of 58 items drawn from previous safety climate studies to represent the six dimensions of safety climate. This section uses a sixpoint Likert scale format ranging from 'strongly disagree' to 'strongly agree'. The selection of an evennumbered scale is preferred for topics where social desirability bias is influential because respondents tend to choose the midpoint rather than confirming an unpopular viewpoint [25].

A major infrastructure project and two medium-rise building projects were selected for questionnaire distribution. The infrastructure project was complex, the first of its kind in Indonesia, and was built by a joint venture of international and large local contractors. The international contractors were known for their advanced construction methods and high level of health and safety implementation. The medium-rise building projects were constructed by large local contractors and a common type of construction project in Indonesia. Comparing the safety climate levels of these two contrasting projects is an important contribution of this research. It was hypothesised that the infrastructure project should have better safety climate than the two other projects because of the experience of the international contractors and the high profile of the project.

Hardcopies of the questionnaire were distributed to construction workers and practitioners in the three projects. Ethics clearance was obtained and all the respondents were told that their responses would be treated with strict confidentiality. They were also provided with opportunities to stop their participation and withdraw their data at any time during the study.

There were 144 valid responses from the infrastructure project and 167 valid responses from the medium-rise projects, bringing the total number of respondents to 311 . The profile of the respondents is presented in Table 1.
Table 1. Profile of respondents.

\begin{tabular}{|c|c|c|c|c|c|}
\hline \multirow[t]{2}{*}{ Profile } & \multirow[t]{2}{*}{ Classification } & \multicolumn{2}{|c|}{ Infrastructure } & \multicolumn{2}{|c|}{ Building } \\
\hline & & $\mathrm{N}$ & $\%$ & $\mathrm{~N}$ & $\%$ \\
\hline \multirow[t]{2}{*}{ Gender } & Male & 137 & 95.14 & 165 & 98.80 \\
\hline & Female & 7 & 4.86 & 2 & 1.20 \\
\hline \multirow[t]{6}{*}{ Age (years) } & $18-24$ & 43 & 31.39 & 50 & 30.30 \\
\hline & $25-34$ & 57 & 41.61 & 48 & 29.09 \\
\hline & $35-44$ & 28 & 20.44 & 46 & 27.88 \\
\hline & $45-54$ & 13 & 9.49 & 16 & 9.70 \\
\hline & 55 and above & 3 & 2.19 & 7 & 4.24 \\
\hline & Average & \multicolumn{2}{|c|}{30.88 years } & \multicolumn{2}{|c|}{32.60 years } \\
\hline \multirow{7}{*}{$\begin{array}{l}\text { Years of } \\
\text { working in } \\
\text { construction }\end{array}$} & $0-4$ & 72 & 50.00 & 141 & 84.43 \\
\hline & $5-9$ & 49 & 34.03 & 8 & 4.79 \\
\hline & $10-14$ & 11 & 7.64 & 9 & 5.39 \\
\hline & $15-19$ & 6 & 4.17 & 3 & 1.80 \\
\hline & $20-24$ & 5 & 3.47 & 2 & 1.20 \\
\hline & 25 and above & 1 & 0.69 & 4 & 2.40 \\
\hline & Average & \multicolumn{2}{|c|}{5.21 years } & \multicolumn{2}{|c|}{3.87 years } \\
\hline
\end{tabular}

The construction industry is widely known as a maledominated industry. This is also the case in the Indonesian construction industry as reflected by the very low proportion of female respondents. Nationally, Indonesia's female labour force participation is far below the male participation and is low relative to countries at a comparable stage of development [26]. Both sets of respondents had similar average ages. In terms of years of working experience in the construction industry, the respondents in the infrastructure project have worked for more than five years on average, while those in the building projects have worked for slightly less than four years on average.

\section{Analysis and Discussion}

Table 2 compare the levels of safety climate between the two project types. A two-sample t-test was used to determine whether the mean difference between the mean scores of each safety climate item is significant or not. For negatively worded items in the questionnaire, the means have been adjusted accordingly.

Table 2. Comparison of safety climate levels in the infrastructure and building projects.

\begin{tabular}{|l|r|r|r|r|c|}
\hline \multirow{2}{*}{ Item } & \multicolumn{2}{|c|}{ Infrastructure } & \multicolumn{2}{c|}{ Building } & $\begin{array}{c}p(\mathrm{t}- \\
\text { test })\end{array}$ \\
\cline { 2 - 6 } & Mean & Rank & Mean & Rank & \\
\hline Management commitment & & & & & \\
\hline $\begin{array}{l}\text { My project manager } \\
\text { considers the safety of } \\
\text { employees a top priority. }\end{array}$ & 4.99 & 3 & 5.14 & 4 & 0.254 \\
\hline $\begin{array}{l}\text { My direct supervisor } \\
\text { allows work to continue } \\
\text { even when unsafe. }\end{array}$ & 4.87 & 12 & 4.99 & 13 & 0.424 \\
\hline $\begin{array}{l}\text { My project manager acts } \\
\text { quickly to correct safety } \\
\text { problems. }\end{array}$ & $\mathbf{4 . 8 1}$ & $\mathbf{1 6}$ & $\mathbf{5 . 2 0}$ & $\mathbf{2}$ & $\mathbf{0 . 0 0 8}$ \\
\hline $\begin{array}{l}\text { My project manager turns } \\
\text { a blind eye to safety } \\
\text { issues. }\end{array}$ & 4.77 & 19 & 4.81 & 26 & 0.777 \\
\hline My project manager & 4.73 & 20 & 4.95 & 17 & 0.144 \\
\hline
\end{tabular}




\begin{tabular}{|c|c|c|c|c|c|}
\hline \multirow{2}{*}{ Item } & \multicolumn{2}{|c|}{ Infrastructure } & \multicolumn{2}{|c|}{ Building } & \multirow{2}{*}{$\begin{array}{l}p(\mathrm{t}- \\
\text { test) }\end{array}$} \\
\hline & Mean & Rank & Mean & Rank & \\
\hline \multicolumn{6}{|l|}{$\begin{array}{l}\text { always implements } \\
\text { corrective actions when } \\
\text { told about unsafe } \\
\text { behaviour or conditions. }\end{array}$} \\
\hline $\begin{array}{l}\text { My direct supervisor pays } \\
\text { attention to my safety. }\end{array}$ & 4.71 & 22 & 4.88 & 24 & 0.262 \\
\hline $\begin{array}{l}\text { My project manager } \\
\text { focuses on safety only } \\
\text { after accidents have } \\
\text { occurred. }\end{array}$ & 4.69 & 23 & 4.77 & 27 & 0.669 \\
\hline $\begin{array}{l}\text { My direct supervisor often } \\
\text { asks employees to begin } \\
\text { the work even though } \\
\text { working conditions are not } \\
\text { safe. }\end{array}$ & 4.68 & $=24$ & 5.00 & 12 & 0.041 \\
\hline $\begin{array}{l}\text { My project manager } \\
\text { expresses concern if safety } \\
\text { procedures are not } \\
\text { adhered to. }\end{array}$ & 4.47 & 35 & 4.27 & 39 & 0.261 \\
\hline Average & 4.75 & & 4.89 & & 0.075 \\
\hline \multicolumn{6}{|l|}{ Safety communication } \\
\hline $\begin{array}{l}\text { Safety communication } \\
\text { makes me pay attention on } \\
\text { safety. }\end{array}$ & 5.07 & 2 & 5.15 & 3 & 0.560 \\
\hline $\begin{array}{l}\text { Safety communication is } \\
\text { effective. }\end{array}$ & 4.94 & 5 & 5.02 & 10 & 0.520 \\
\hline $\begin{array}{l}\text { I receive a lot of } \\
\text { information about safety. }\end{array}$ & 4.93 & 6 & 4.98 & 14 & 0.650 \\
\hline $\begin{array}{l}\text { Safety information is } \\
\text { always brought to my } \\
\text { attention by my direct } \\
\text { supervisor. }\end{array}$ & 4.92 & $=7$ & 5.06 & 8 & 0.220 \\
\hline $\begin{array}{l}\text { I receive constructive } \\
\text { suggestions if I work } \\
\text { unsafely. }\end{array}$ & 4.92 & $=7$ & 4.94 & $=18$ & 0.858 \\
\hline $\begin{array}{l}\text { Safety information is } \\
\text { always up to date. }\end{array}$ & 4.86 & 13 & 4.95 & $=16$ & 0.469 \\
\hline $\begin{array}{l}\text { My project manager is } \\
\text { available for discussion } \\
\text { when it comes to safety. }\end{array}$ & 4.72 & 21 & 4.91 & 22 & 0.147 \\
\hline $\begin{array}{l}\text { My direct supervisor } \\
\text { never discusses safety } \\
\text { issues with me. }\end{array}$ & 4.16 & $=40$ & 4.33 & 38 & 0.316 \\
\hline $\begin{array}{l}\text { Methods used to } \\
\text { communicate safety } \\
\text { information are inadequate }\end{array}$ & 3.51 & $=50$ & 3.84 & 48 & 0.067 \\
\hline Average & 4.67 & & 4.80 & & 0.078 \\
\hline \multicolumn{6}{|l|}{$\begin{array}{l}\text { Safety rules and } \\
\text { procedures }\end{array}$} \\
\hline $\begin{array}{l}\text { Safety procedures are } \\
\text { carefully followed by all. }\end{array}$ & 4.88 & 11 & 5.12 & 5 & 0.066 \\
\hline $\begin{array}{l}\text { Some safety rules and } \\
\text { procedures do not need to } \\
\text { be followed to get the job } \\
\text { done safely. }\end{array}$ & 4.51 & 34 & 4.69 & 31 & 0.236 \\
\hline $\begin{array}{l}\text { Sometimes safety } \\
\text { procedures are overlooked } \\
\text { to meet production targets. }\end{array}$ & 3.84 & 44 & 4.26 & 40 & 0.020 \\
\hline $\begin{array}{l}\text { Some safety rules and } \\
\text { procedures are difficult to } \\
\text { understand. }\end{array}$ & 3.81 & 45 & 4.19 & 45 & 0.027 \\
\hline $\begin{array}{l}\text { Sometimes it is necessary } \\
\text { to ignore safety } \\
\text { requirements to get a job } \\
\text { done. }\end{array}$ & 3.77 & $=46$ & 4.14 & 46 & 0.044 \\
\hline $\begin{array}{l}\text { Some safety procedures } \\
\text { are difficult to implement. }\end{array}$ & 3.51 & $=50$ & 3.80 & 50 & 0.124 \\
\hline Average & 4.05 & & 4.37 & & 0.003 \\
\hline \multicolumn{6}{|l|}{ Supportive environment } \\
\hline $\begin{array}{l}\text { My co-workers often give } \\
\text { tips to each other on how } \\
\text { to work safely. }\end{array}$ & 4.91 & 9 & 5.01 & 11 & 0.433 \\
\hline Employees are always & 4.83 & $=14$ & 5.04 & 9 & 0.142 \\
\hline
\end{tabular}

\begin{tabular}{|c|c|c|c|c|c|}
\hline \multirow[t]{2}{*}{ Item } & \multicolumn{2}{|c|}{ Infrastructure } & \multicolumn{2}{|c|}{ Building } & \multirow{2}{*}{$\begin{array}{l}p(\mathrm{t}- \\
\text { test })\end{array}$} \\
\hline & Mean & Rank & Mean & Rank & \\
\hline \multicolumn{6}{|l|}{$\begin{array}{l}\text { encouraged to focus on } \\
\text { safety at their workplace. }\end{array}$} \\
\hline $\begin{array}{l}\text { There is no punishment } \\
\text { for behaving unsafely. }\end{array}$ & 4.68 & $=24$ & 4.64 & 32 & 0.814 \\
\hline $\begin{array}{l}\text { No one criticises me if I } \\
\text { remind someone to work } \\
\text { safely. }\end{array}$ & 4.63 & 29 & 4.76 & 28 & 0.427 \\
\hline $\begin{array}{l}\text { I am strongly encouraged } \\
\text { to report unsafe conditions } \\
\text { in my workplace. }\end{array}$ & 4.53 & $=31$ & 4.73 & 29 & 0.189 \\
\hline $\begin{array}{l}\text { There are always enough } \\
\text { people available to get the } \\
\text { job done safely. }\end{array}$ & 4.46 & $=36$ & 4.53 & 35 & 0.625 \\
\hline $\begin{array}{l}\text { My co-workers do not } \\
\text { care whether I am working } \\
\text { safely or not. }\end{array}$ & 4.32 & 39 & 4.38 & $=36$ & 0.726 \\
\hline $\begin{array}{l}\text { I receive praise for } \\
\text { working safely. }\end{array}$ & 4.16 & $=40$ & 4.56 & 34 & 0.012 \\
\hline $\begin{array}{l}\text { It's hard for me to work } \\
\text { safely at my workplace. }\end{array}$ & 4.03 & 43 & 4.24 & 43 & 0.217 \\
\hline $\begin{array}{l}\text { Employees who report } \\
\text { safety issues will be } \\
\text { punished by their } \\
\text { colleagues. }\end{array}$ & 3.77 & $=46$ & 4.01 & 47 & 0.192 \\
\hline $\begin{array}{l}\text { I cannot always get the } \\
\text { tools or equipment I need } \\
\text { to do the job safely. }\end{array}$ & 3.51 & $=50$ & 4.20 & 44 & 0.000 \\
\hline $\begin{array}{l}\text { Sometimes workplace } \\
\text { conditions hinder my } \\
\text { ability to work safely. }\end{array}$ & 3.49 & 53 & 3.46 & 54 & 0.892 \\
\hline $\begin{array}{l}\text { Sometimes I am not given } \\
\text { enough time to get the job } \\
\text { done safely. }\end{array}$ & 3.45 & 54 & 3.79 & 51 & 0.062 \\
\hline $\begin{array}{l}\text { Work targets often } \\
\text { conflict with safety } \\
\text { measures. }\end{array}$ & 3.42 & 55 & 3.54 & 53 & 0.486 \\
\hline $\begin{array}{l}\text { I think my work } \\
\text { environment increases the } \\
\text { possibility of accidents }\end{array}$ & 3.34 & 56 & 3.25 & 56 & 0.644 \\
\hline Average & 4.10 & & 4.28 & & 0.014 \\
\hline \multicolumn{6}{|l|}{$\begin{array}{l}\text { Personal safety } \\
\text { involvement and needs }\end{array}$} \\
\hline $\begin{array}{l}\text { A safe place to work is } \\
\text { very meaningful for me. }\end{array}$ & 5.23 & 1 & 5.38 & 1 & 0.112 \\
\hline $\begin{array}{l}\text { Safety is the number one } \\
\text { priority for me when } \\
\text { completing a job. }\end{array}$ & 4.97 & 4 & 5.08 & 7 & 0.316 \\
\hline $\begin{array}{l}\text { A continuing emphasis on } \\
\text { safety is important for me. }\end{array}$ & 4.90 & 10 & 5.09 & 6 & 0.142 \\
\hline $\begin{array}{l}\text { I understand all the safety } \\
\text { rules. }\end{array}$ & 4.80 & 17 & 4.97 & 15 & 0.168 \\
\hline $\begin{array}{l}\text { I feel that my workplace } \\
\text { has met the required safety } \\
\text { standards. }\end{array}$ & 4.68 & $=24$ & 4.93 & $=20$ & 0.042 \\
\hline $\begin{array}{l}\text { I am clear about my health } \\
\text { and safety responsibilities. }\end{array}$ & 4.66 & 27 & 4.89 & 23 & 0.095 \\
\hline $\begin{array}{l}\text { When people ignore safety } \\
\text { procedures, it's not } \\
\text { necessary to report them. }\end{array}$ & 4.65 & 28 & 4.57 & 33 & 0.613 \\
\hline $\begin{array}{l}\text { I am involved in } \\
\text { implementing safety at } \\
\text { work. }\end{array}$ & 4.53 & $=31$ & 4.71 & 30 & 0.246 \\
\hline $\begin{array}{l}\text { It is only a matter of time } \\
\text { before I am involved in an } \\
\text { accident. }\end{array}$ & 4.46 & $=36$ & 4.38 & $=36$ & 0.639 \\
\hline $\begin{array}{l}\text { I do what I am told to do } \\
\text { and don't want to be } \\
\text { bothered with safety } \\
\text { policy. }\end{array}$ & 4.11 & 42 & 3.74 & 52 & 0.049 \\
\hline $\begin{array}{l}\text { I can influence safety } \\
\text { performance in my } \\
\text { workplace. }\end{array}$ & 3.63 & 48 & 3.81 & 49 & 0.339 \\
\hline My responsibility is to & 3.56 & 49 & 3.41 & 55 & 0.428 \\
\hline
\end{tabular}




\begin{tabular}{|c|c|c|c|c|c|}
\hline \multirow[t]{2}{*}{ Item } & \multicolumn{2}{|c|}{ Infrastructure } & \multicolumn{2}{|c|}{ Building } & \multirow{2}{*}{$\begin{array}{l}p(\mathrm{t}- \\
\text { test })\end{array}$} \\
\hline & Mean & Rank & Mean & Rank & \\
\hline \multicolumn{6}{|l|}{$\begin{array}{l}\text { work safely, and not to } \\
\text { report co-workers who do } \\
\text { not work safely. }\end{array}$} \\
\hline $\begin{array}{l}\text { I am worried about being } \\
\text { injured on the job. }\end{array}$ & 3.18 & 57 & 3.17 & 57 & 0.972 \\
\hline $\begin{array}{l}\text { There's always a } \\
\text { possibility that I will have } \\
\text { an accident in my } \\
\text { workplace. }\end{array}$ & 3.08 & 58 & 2.93 & 58 & 0.425 \\
\hline Average & 4.32 & & 4.36 & & 0.439 \\
\hline \multicolumn{6}{|l|}{ Safety training } \\
\hline $\begin{array}{l}\text { The safety training } \\
\text { provided is practical. }\end{array}$ & 4.83 & $=14$ & 4.93 & $=20$ & 0.428 \\
\hline $\begin{array}{l}\text { Potential risks and } \\
\text { consequences are } \\
\text { identified in safety } \\
\text { training. }\end{array}$ & 4.79 & 18 & 4.94 & $=18$ & 0.233 \\
\hline $\begin{array}{l}\text { I received adequate } \\
\text { training to perform my job } \\
\text { safely. }\end{array}$ & 4.62 & 30 & 4.84 & 25 & 0.109 \\
\hline $\begin{array}{l}\text { The company invests a lot } \\
\text { of time and money in } \\
\text { safety training. }\end{array}$ & 4.53 & $=31$ & 4.25 & $=41$ & 0.062 \\
\hline $\begin{array}{l}\text { I am capable of } \\
\text { identifying potentially } \\
\text { hazardous situations. }\end{array}$ & 4.39 & 38 & 4.25 & $=41$ & 0.394 \\
\hline Average & 4.63 & & 4.64 & & 0.908 \\
\hline Total average & 4.38 & & 4.51 & & 0.016 \\
\hline
\end{tabular}

On average, both sets of respondents agreed (albeit slightly) that safety climate in their projects was satisfactory. However, a significant difference was found between the safety climate levels in the two project types. In contrary to the hypothesis, the safety climate level in the infrastructure project was lower than the level in the building projects. The project that was managed by the international joint venture known for its health and safety commitment was perceived to have lower safety climate than the projects managed by local contractors. As stated earlier, the infrastructure project is the first of its kind in Indonesia and, as such, is inherently complex. Project complexity is an important factor that affects project performance [27] and this finding confirms the influence of project complexity on health and safety performance. In such a complex project, project stakeholders should collaborate to identify factors affecting project complexity and choose methods to mitigate or manage those factors in the early stages of project planning [28]. Health and safety consideration should become an integral part of these project planning sessions.

Examining the individual dimensions, there are significant differences between the two project types. The infrastructure project was perceived to have lower levels of safety climate than the building projects in terms of the safety rules and procedure dimension and the supportive environment dimension. Underpinned by the project complexity theories, complex projects require more stringent enforcement of safety rules and procedures. As indicated by individual items within this dimension, the resources needed to implement health and safety measures should be included in project planning and scheduling. Likewise, in complex projects, there needs to be stronger supportive environments to motivate people to focus on health and safety. In this case, a high degree of trust and support in the workplace that promote positive relationships with superiors, relationships with co-workers, and overall work conditions that are conducive to health and safety is paramount.

Finally, looking at the individual items, considerable improvements are needed to improve the items perceived lowly by both sets of respondents. All the respondents perceived that unrealistic work targets hinder their ability to work safely and increase the probability of accidents. The respondents also worried about being injured or involved in an accident in the workplace. These perceptions indicate that the respondents considered accidents and injuries as a normal part of working in the construction industry. Currently health and safety is not a priority in the Indonesian construction industry where project stakeholders are mostly concerned with time and cost performances [29]. The low level of unionisation and the lack of enforcement of health and safety regulations in the industry may be other factors that further cause this lack of priority towards OSH.

\section{Conclusions}

This research has assessed and compared the levels of safety climate in an infrastructure project and mediumrise building projects in the Indonesian construction industry. The findings indicate that the safety climate in the infrastructure project is lower than the safety climate in the building projects even though the infrastructure project was managed by a joint venture organisation involving international contractors known for their health and safety commitment. The infrastructure project is the first of its kind in Indonesia and is extremely complex. Project complexity is a well-known factor that affects project success and this research confirms its influence on health and safety performance. In the context of this research, complex construction projects require stringent enforcement of safety rules and procedures. Supportive work environments in the forms of high degree of trust and support among project stakeholders to develop conducive environment to work safely is another important factor to implement health and safety in complex projects. Factors affecting project complexity and methods to mitigate or manage those factors should be identified by project stakeholders in the early stages of project planning.

In general, the respondents perceived that the levels of safety climate in both types of projects were accepTable. However, two groups of items were lowly ranked by the respondents, thus requiring improvements. First, the respondents perceived that work targets hinder health and safety implementation. Second, they perceived that accidents are normal occurrences on construction sites, causing them to worry to get injured at work. Stronger enforcement of health and safety regulation in the industry is needed to change these perceptions. At the same time, project stakeholders should realise the social and economic benefits of health 
and safety in construction projects. Research has consistently shown that effective health and safety implementation increases productivity, improves the bottom line of the project, and reduces the cost impacts of workplace accidents and injuries on the national economy.

\section{References}

1. S. Epifany, J. Scopacasa, Indonesia's Construction Market to Grow 8\% in 2017 (Tarsus Indonesia, Jakarta, Indonesia, 2017), available from: https://konstruksi-indonesia-big-

5.prezly.com/indonesias-construction-market-togrow-8-in-2017 (Accessed on 20 Feb 2018).

2. Kementrian Keuangan Republik Indonesia, $A P B N$ 2018 (Kementrian Keuangan Republik Indonesia, Jakarta, Indonesia, 2018), available from: https://www.kemenkeu.go.id/apbn2018 (Accessed on 4 April 2018).

3. Indonesian Government, Peraturan Pemerintah Republik Indonesia Nomor 50 Tahun 2012 Tentang Penerapan Sistem Manajemen Keselamatan dan Kesehatan Kerja (Indonesian Government, Jakarta, Indonesia, 2012).

4. BPJS Ketenagakerjaan, Angka Kasus Kecelakaan Kerja Menurun. BPJS Ketenagakerjaan (Indonesian Government, Jakarta, Indonesia, 2016).

5. M.N. Rochmi, Kecelakaan kerja sektor konstruksi paling tinggi, Jakarta, Indonesia (2016), available from: https://beritagar.id/artikel/berita/kecelakaankerja-sektor-konstruksi-paling-tinggi (Accessed on 15 Aug 2017).

6. R.A. Musa, A. Fadhli, Y. Kusminanti, D. Erwandi, F. Lestari, Behaviour intention analysis among workers at oil and gas company, SPE/IATMI Asia Pacific Oil \& Gas Conference and Exhibition, 20-22 October, Nusa Dua, Bali, Indonesia (2015).

7. P.X.W Zou, R.Y. Sunindijo, Strategic Safety Management in Construction and Engineering. Wiley Blackwell, Chichester, UK, 2015).

8. N. Dedobbeleer, F, Béland, Is risk perception one of the dimensions of safety climate? In: A. Feyer, A. Williamson (Eds.), Occupational Injury: Risk Prevention and Intervention, pp. 73-81 (Taylor \& Francis, London, UK, 1998).

9. S. Mohamed, Safety climate in construction site environments, Journal of Construction Engineering and Management, 128, 5, 375-384 (2002).

10. F. Davies, R. Spencer, K. Dooley, Summary Guide to Safety Climate Tools (HSE Books, Norwich, UK, 2001).

11. D. Seo, M. Torabi, E. Blair, N. Ellis, A crossvalidation of safety climate scale using confirmatory factor analytic approach, Journal of Safety Research, 35, 4, 427-445 (2004).

12. D. Zohar, Safety climate in industrial organizations: Theoretical and applied implications, Journal of Applied Psychology, 65, 1, 96-102 (1980).

13. B.F. Muñiz, J.M. Montes-Peón, C.J. VázquezOrdás, Safety culture: Analysis of the causal relationships between its key dimensions, Journal of Safety Research, 38, 6, 627-641 (2007).

14. Health and Safety Executive, A Review of Safety Culture and Safety Climate Literature for the Development of the Safety Culture Inspection Toolkit (HSE Books, Bristol, UK, 2005).

15. M.D. Cooper, Towards a model of safety culture, Safety Science, 36, 2, 111-136 (2000).

16. F.W. Guldenmund, The nature of safety culture: A review of theory and research, Safety Science, 34, 13, 215-257 (2000).

17. J.M. Beus, S.C. Payne, W. Arthur, Jr., G.J. Muñoz, The Development and Validation of a CrossIndustry Safety Climate Measure: Resolving Conceptual and Operational Issues. Journal of Management, DOI10.1177/0149206317745596 (2017).

18. S. Clarke, Safety climate in an automobile manufacturing plant: The effects of work environment, job communication and safety attitudes on accidents and unsafe behaviour, Personnel Review, 35, 4, 413-430 (2006).

19. A. Neal, M.A. Griffin, P.M. Hart, The impact of organizational climate on safety climate and individual behaviour, Safety Science, 34, 1-3, 99109 (2000).

20. A.M. Williamson, A. Feyer, D. Cairns, D. Biancotti, The development of a measure of safety climate: The role of safety perceptions and attitudes, Safety Science, 25, 1-3, 15-27 (1997).

21. Andi, Construction workers perceptions towards safety culture, Civil Engineering Dimension, 10, 1, 1-6 (2008).

22. R.A. Machfudiyanto, Y. Latief, Y. Yogiswara, R.M.F. Setiawan, Structural equation model to investigate the dimensions influencing safety culture improvement in construction sector: A case in Indonesia, AUO Conference Proceedings, 1855, 030019 (2017).

23. I.Z. Sutalaksana, D.H. Syaifullah, Factors influencing Indonesian construction workers safety behavior based on Seo's model, The 9th Southeast Asian Ergonomics Society Conference, Bangkok, Thailand, 22-24 October (2008).

24. T.S. Irawadi, Structural equation modelling of climate safety and personal competency against the safe behaviour and its implications on the performance of construction projects, Journal of Basic and Applied Scientific Research, 6, 4, 72-81 (2016).

25. R. Johns, One size doesn't fit all: Selecting response scales for attitude items. Journal of Elections, Public Opinion and Parties, 15, 2, 237-264 (2005).

26. The Australia Indonesia Partnership for Economic Governance (AIPEG), the Australian Department of Foreign Affairs and Trade, and Monash University, Women's Economic Participation in Indonesia, AIPEG, Australia (2017).

27. A.P.C. Chan, D. Scott, A.P.L. Chan, Factors affecting the success of a construction project, Journal of Construction Engineering and Management, 130, 1, 153-155 (2004). 
28. E. Mirza, N. Ehsan, Quantification of project execution complexity and its effect on performance of infrastructure development projects, Engineering Management Journal, 29, 2, 108-123 (2017).

29. A. Soekiman, K.S. Pribadi, B.W. Soemardi, R.D. Wirahadikusumah, Factors relating to labor productivity affecting the project schedule performance in Indonesia, Procedia Engineering, 14, 865-873 (2011). 